\title{
FEDERAL REVENUE SHARING, MARGINALISATION AND SUB-NATIONAL INTER-REGIONAL INEQUALITY IN HUMAN CAPITAL DEVELOPMENT IN SOUTH-EASTERN AND SOUTHERN NIGERIA
}

\author{
RICHARD INGWE \\ Institute of Public Policy and Administration, University of Calabar, and Centre for Research and Action \\ on Developing Locales, Regions and the Environment, Calabar, Nigeria \\ JOSEPH K. UKWAYI \\ Department of Sociology, University of Calabar, Calabar, Nigeria \\ EDWARD U. UTAM \\ Department of Political Sciences, University of Calabar, and Centre for Research and Action on Developing \\ Locales, Regions and the Environment, Calabar, Nigeria
}

Manuscript received: December 15, 2012

Revised version: May 6, 2013

INGWE R., UкWAYI J.K., UtAм E.U., 2013. Federal revenue sharing, marginalisation and sub-national inter-regional inequality in human capital development in south-eastern and southern Nigeria. Quaestiones Geographicae 32(2), Bogucki Wydawnictwo Naukowe, Poznań, pp. 51-68. 1 table, 1 fig. DOI 10.2478/quageo-2013-0013, ISSN 0137477X.

AвSTRACT. Regional development planning/management responds to needs for preventing inequality among regions within nations characterised by multi-culturality and variation among regions, through the planning/management of appropriate programmes and policies. This paper examines inequality in the development of two of Nigeria's states in the geographical South-East and the political South-South. Among other issues, historical conflicts among various ethno-cultural groups constituting Nigeria and culminating in violence (e.g. the 1967-1970 civil war fought against the programme of Ibo (a socio-cultural group) seceding from Nigeria's federation to found Biafra) are reviewed. Despite Nigeria's tragic civil war, inequality persists. We examine inequality resulting from systematic implementation of policies/programmes of Nigeria's federal government institutions that marginalise Cross River State. Using the methods of comparative analysis and a descriptive case study, we show the consequences of marginalisation policies implemented by the federal government alone or in collaboration with (i.e. in support of) Akwa Ibom State for the development of human capital in Cross River State. The specific acts of marginalisation referred to here include: the ceding of the Bakassi Peninsula - a part of Cross River State - to the Republic of Cameroon in 2005, and more recently (2009) another ceding of 76 oil wells, hitherto the property of Cross River State, to Akwa Ibom State. We argue that, strengthened by marginalising/polarising policies (higher revenue allocation based on derivation principle of oil production), Akwa Ibom's ongoing implementation of free education policy 
promises to facilitate its achievement of millennium development goals in basic education by 2015, beyond which it might reach disproportionately higher levels of tertiary educational attainment by 2024 and after. By contrast, the contrived dwindling of oil revenue accruing to Cross River State deprives it of funding for competitive human capital development programme(s). We recommend that Cross River State employs serious monitoring of marginalising schemes against its people considering recent traumatising experience, and plan/implement human capital development programmes aimed to improve its competitiveness under the context of intra-regional inequality.

KEY WORDS: inequality, sub-national, region, marginalisation, competitiveness, human capital, development, states

Richard Ingwe, Institute of Public Policy and Administration (IPPA), University of Calabar, P.M.B. 1115, Calabar, Nigeria; e-mail: ingwe.richard@gmail.com, cradle.africa@gmail.com.

\section{Introduction}

Within the past decade - or thereabouts a myriad new development issues have aroused the interest of human geographers, most of whom undertook to devise and apply geographies of neoliberalism and neoliberalisation to gain an understanding of their intricacies. By doing so, those human geographers have brought about a rapid expansion of theoretical and conceptual aspects of those new sub-disciplines of human geography. Some of those emerging issues could be described as ones of upsurge in the geographies of neoliberalism and/or neoliberalisation, ranging "from cities to citizenship, sexuality to subjectivity, and development to discourse, to name but a few" (Springer 2012a: 135). Recently, the literature in the fields of spatial and/or regional development planning and management has witnessed increasing interest of scholars in issues that were hitherto ignored but that bear relevance to national and sub-national development outcomes. For example, in eulogising the benefit of trust in national development, Alex A. Pereira has applied the class-relations perspective to show that the dominance of the developmental state involving about 40 years of steady economic growth in Singapore is attributable to the way the capitalist state has collaborated with trans-national capital in the absence of a domestic capitalist class, thereby distinguishing this developmental state from its East Asian counterparts (Pereira 2007). It is worth recalling that Singapore - where growth has occurred - is one of the 12 sustainable growth economies which had experienced growth rates of at least seven per cent per year for a quarter of a century at the time those countries were studied (Bayer 2009: 91-92 citing Spence 2008). The economic growth experience of other developing countries outside those of sustainable growth was not as good, thereby warranting research aimed at formulating solutions to the challenges they face.

\section{Conceptualising African- Nigerian development challenges: From general neoliberalism/ neoliberalisation to marginalisation}

Neoliberalism and neoliberalisation are increasingly applied to conceptualise a myriad development challenges facing Africa, including Nigeria. In highlighting some national development challenges faced by sub-Saharan countries in the context of neoliberal globalisation, it was found that Nigeria had attained high levels of implementation of neoliberal policies by the mid1980s (Ingwe et al. 2010) and perhaps onwards. Although regional investments in education (especially the funding of education programmes and establishment of institutions, among others) as instruments catalysing economic growth by increasing human capital, productivity and competitiveness at the sub-national regional level have been explored (Ingwe et al. 2011), the role of neoliberalism in the process is yet to receive scholarly attention. We shift emphasis from general aspects of neoliberalism and neoliberalisation to their more specific characteristics (marginalisation) because the latter have been fairly well examined in our previous works that acknowledge and implicate the force of neoliberalism and neoliberalisation in their expansion or development. 
Among the many development issues in Nigeria we have studied in terms of theoretical conceptualisations founded on neoliberalism is an outline of a global research agenda examining a myriad themes emphasised by Nigeria's successive heads of states and federal government administrations. With the baseline of study fixed at 1960 - the year Nigeria was granted political independence by British colonialists but devoid of substantial social and economic freedom - we attempted to trace the implementation of policies of a neoliberal kind from then up to the end of the third term of Nigeria's Fourth Republic, 2007 (Ingwe et al. 2012). Other studies have justified or explained the federal government's intervention in the Hausa-Fulani socio-cultural education (Almajiri) system in northern Nigeria (Ingwe 2013a), sustainable energy implementation in urban $\mathrm{Ni}$ geria (Ingwe et al. 2009), an equivocal response of Nigeria's federal parliament to the independent management of the economy by the country's Central Bank (Ingwe 2013b), and governance deficits that seem to catalyse the nationalisation of sub-national rebellions in Nigeria. An example of the last process was the January 2012 rebellion against oil subsidy removal that provoked the emergence of nation-wide revolutionary forces (Ingwe 2013c). In all of the studies listed above, marginalisation - one of the dimensions of neoliberalism and neoliberalisation - has never been used as a concept to understand how specific sub-national regions or socio-cultural groups get into intense suppression through deliberate policy making and implementation.

To conceptualise marginalisation as one variety of neoliberalism, our point of departure is the claim by a human geographer, Simon Springer, about the coalescence of neoliberalism with violence in a fluid process wherein the resulting hegemony of neoliberalism exhibits abuse and widespread banishment of 'Others' almost perpetually in the many areas undergoing neoliberalisation. He argues that "the widespread banishment of 'Others' under neoliberalism produces a 'state of exception', wherein, because of its inherently dialectic nature, exceptional violence is transformed into exemplary violence". Springer claims that this transformation occurs as aversion for alterity intensifies - a phenomenon that becomes the rule and undergoes intensification under neoliberalism (Springer 2012b: 136). This process is conceived in the present article as a spectrum in the intensification of violence within which marginalisation constitutes one of the many bands.

The focus of this article on aspects of limited trust in the latter situation (Nigeria) is purposeful: this is where the implementation of policies promoting justice, equality, and fairness among regions constituting a nation are most required, vital as they are to promoting much-needed nation-building and sustainable regional development. The requirements for the foregoing conditions prompt increasing advocacy of creating peaceful and harmonious structures, processes, institutions, and attitudes within nations, especially in states whose multi-cultural characteristics pose challenges to harmonious co-existence. Unequal opportunities for the development of one or more regions, areas, communities, ethno-cultural groups in a heterogeneous human population have been recognised as one of the challenges that face most national development managements.

Nigeria's post-independent socio-political history is tainted by the so-called civil war waged for 30 months, from 1967 to 1970, by armed forces of what came to be known as the federal government side, comprising two major sub-national regions (West and North), against the third region (East). It was a response to the declaration of independence, i.e. secession from the Nigerian Federation founded only seven years after independence (1960), by the Eastern Region under the governorship of Major Emeka Odumegwu Ojukwu, with a substantial proportion of its population deriving from the Ibo socio-cultural group, who charged that the federal government implemented policies that marginalised them. Although this rebellion is the one best known, it was crushed like the pioneering rebellion against the federal government breaking out under the auspices of the (Niger) Delta Volunteer Service (DVS) in 1966. This rebellion involved the mobilisation of dissenting people of the Niger Delta, especially those from the old River State comprising the current River and Bayelsa under the leadership of Isaac Adaka Boro (Osaghae et al. 2007). Despite the recurrent rebellions waged since independence by various groups of civil 
society to gain attention and receive favourable policies from the Nigerian Federation, evidence shows that the policies currently implemented by the federal government of Nigeria have retained the characteristics of marginalisation perceived by the socio-cultural minority groups of the old River State and the Ibos of the South-Eastern Region shortly after independence in 1960.

Owing to the serious consequences of contrived or naturally occurring circumstances that create inequality in the development of some regions within one nation, governments of some countries which have experienced agitations (sometimes violent) from particular human groups perceiving their region to be treated unjustly or marginalised, have sought to undertake development planning strategies which deliberately strive to equalise, as much as possible, the opportunities, chances and resources that can engender equality in the development of regions that constitute the nation. Some known charges of marginalisation at the global level have been reported in the literature. Perhaps the best known example of this form of racist or discriminatory human relations popularly called anti-Semitism in Europe involves the Jews, who have long charged the Nazis of marginalisation.

In the United States of America, African-Americans and American Indians, or Native Americans, have charged the US government and its top functionaries with applying a rule of marginalisation that historically has led to the destruction of their people. In Australia, the Aborigines have complained against marginalisation. The Berbers' charge of marginalisation against their people seems to be one of the best known (Igwe 2005).

Whether real or imagined, marginalisation presents a useful approach towards understanding the degree of harmony or disharmony within a particular nation. That is, it offers a framework for assessing the way its government guarantees or sustains social order necessary for national economic growth and development. This article examines a recent move towards marginalisation of Cross River State since March 2009 and the possible consequences of such policies. It involves the seizure by federal agencies of the state's 76 petroleum oil wells and handing them over to Akwa Ibom State leading to the striking of
Cross River State from the list of Nigeria's littoral states receiving special allocations based on the principle of derivation of national revenue from particular parts of the country. The action has led to a drastic reduction in the income of Cross River State, thereby hampering its development programmes, including human capital development programmes such as education and health care.

In this article we describe the marginalising policies implemented by the Nigerian federal government through its agencies and how this results in a discrimination against one of the federation's constituent sub-national regions (states) while benefiting another. We focus on one aspect of the marginalisation policies, namely the unequal sharing of financial resources collected into a common pool and managed by the federal government. In order to demonstrate the virulence of marginalisation by federal agencies, we decided to examine the manifestation of this problem in two of Nigeria's 36 states (Akwa Ibom and Cross River) that previously shared common geographical boundaries, socio-political histories and institutions within the South-South geopolitical region (formerly the South-Eastern geographical zone). Specifically, we show how declining federal revenue going to Cross River State and increasing revenue allocated to its neighbour, Akwa Ibom, threatens to hamper the former's human capital development while the latter progresses apace. National and regional newspapers as well as Cross River radio news, commentaries and advertorials reported around June 2009 that before Cross River State's 76 oil wells had been seized in mid-2009, Akwa Ibom State had sufficient means to fund its free education programme at all levels of the education system. This was made possible by its receipt of a larger revenue allocation (14 billion naira ${ }^{1}$ monthly) than Cross River State's 1.5 billion, after the seizure of the 13\% derivation fund to the state resulting from unjust decisions of Nigeria's National Boundary Commission (NBC) and the Revenue Mobilisation and Fiscal Commission (RMAFC) via a letter issued by the NBC on 4 January 2009 (Adekeye et al. 2009: 38).

\footnotetext{
The exchange rate of US \$1 was 155.23 as of 25 January 2013.
} 


\section{Marginalising as a means to achieve political hegemony in Nigeria}

Irrespective of the role played by peace, unity and social order in facilitating national economic growth and development through social capital, mutual trust and harmony that they inculcate into various groups which form the nation, the successive governments of the Nigerian Federation seem either to have been ignorant of its relevance or to have downplayed it, or misunderstood its distinctive significance. The marginalising disposition of Nigeria's federal government is easily understood in the light of the following brief political history of the country. The present Nigerian federation is the creation of British colonialists. The colonial era involved the amalgamation in 1914 of two major socio-cultural human groups broadly described as the Northern and Southern Protectorates of Nigeria by Sir Frederick Lugard, who then served the British Empire as Governor-General of Nigeria. A point that has been ignored in most contributions to the literature is that the two protectorates comprised multiple autonomous ethnic nationalities forcefully coalesced into a monolithic entity by the British colonial machinery.

At this juncture it is worth noting the failure of this coercive colonial action to forge a union between the protectorates and their constituent ethnic nationalities as well as its failure to respect the views and integrities of their political leaders during the process and in the subsequent power shift from the British colonialists to the indigenous élite. The massive plunder of Nigeria's human and natural resources by the British colonialists led to strong agitation for independence, including socio-economic and political freedoms. Regrettably, the brand of independence achieved on 1 October 1960 was a merely political or flag type. This derogatory description is a reflection of the serious and prolonged or chronic poverty afflicting a disproportionately large segment of Nigeria's population. Despite the recent claims of high economic growth rates of about six percent, serious poverty - in 1997 an estimated 70.2 and 90.8 percent of Nigerians lived on less than US $\$ 1$ and US $\$ 2$ per day, respectively (WRI, UNDP, UNEP \& World Bank, 2005) - is yet to be reduced. Therefore, a majority of poor Nigerians are also affected by inequality, injustice and deprivation. Some people argue that this political dynamics represents a mere shift of power from British colonialists to a corrupt, parasitic indigenous élite, unrelenting in depriving Nigerians of their desired socio-economic freedoms. This seems to be especially the views expressed by excluded Nigerians from cultural groups perceived or treated as minorities, but sometimes also by large populations of the poor in the majority ethnic groups.

Since the view of progressive Nigerians that "Only a good government can stop corruption" is yet to be translated into reality given the rampart and thriving corruption perpetrated by the country's élite, the poor and unfairly treated population strata have resorted to frequent charges of corruption based on socio-cultural platforms cutting across the entire spectrum of the country.

The disregard of British colonialists for the existing political leaders of the various ethnic nationalities that were forcefully coalesced into the protectorates to fabricate Nigeria requires mention at this juncture to consider the effectiveness of government. Note that the handover of political power by the British to the indigenous élite happened in ways resembling the methods of colonialism itself: without the participation of the existing political leadership of ethnic nationalities. This point is acknowledged as the parallel occurrence of two governments, namely modern and traditional. The latter is synonymous with political leadership of ethnic nationalities at various levels, while the former represents indigenous rulers or successors of colonialists. The indigenous élite's failure to use the power they inherited to mobilise and galvanise support from the existing political leaders, perhaps in their preoccupation with or concentration on corruption and primitive capital accumulation, has resulted in serious discontentment with their bad government. However, traditional ruling institutions of northern Nigeria were secretly involved in the shift of power from colonialists to indigenous educated élites, unlike in southern Nigeria. It has been suggested that this British action aimed to achieve their socio-economic and political interests by their preference to assist Northern Nigerians to maintain hegemony over their Southern counterparts. Therefore, while Northern Nigerians - both the military and civilians - 
dominated the federal government from 1960 to 1999 and also from 2007 to 2011, the ascendance of Southern Nigerians to the top echelons of the federal government resulted only from tumultuous socio-political and economic circumstances capable of fragmenting the country. This, however, is outside the scope of the present article. The foregoing explains the rampart marginalisation charges against the federal government of Nigeria as dominated by Northern Nigerians.

Among the various groups that have charged the federal government of Nigeria with marginalisation are the Ibos of south-eastern Nigeria, whose quarrels with the federal government during the First Republic (1960-1967), still persisting, culminated then in ethnic hostilities and a 30-month civil war (1967-1970). Others have included the agitation by the people of the oil-rich Niger Delta region (from the western Benin River to the Imo River) against the unjust exploitation of their fossils (oil and natural gas) since their extraction started in the late 1950s; a charge by the Hausa-Fulani people of northern Nigeria against the Obasanjo administration (1999-2007); and the agitation by the Yoruba people of south-western Nigeria against what they perceived as ethnic-cleansing policy against them by the dictatorship of General Sani Abacha (1993-1997), among other less obvious or publicised cases.

Despite the rather high frequency and recurrence of marginalisation charges in Nigeria, their documentation has lagged behind their seriousness. National development planning and management in Nigeria has consequently been hampered by the inadequacy of information and knowledge which ought to have been provided to found the practice of development management in the country (represented by a socio-cultural group called Ohanaeze). Perhaps most explicit was the submission by the Ibos, in October 1999, of the documentation of human rights violations and injustices done against them by the Nigerian Federation and a request for reparations during the Human Rights Violations Investigating Committee (a.k.a. the Justice Oputa Panel, named after the chairman of the Committee, a retired justice of Nigeria's Supreme Court, Chukwudi Oputa). This document highlighted sufferings of the Ibos, including the bloodshed of 1966 killings of General Aguiyi Ironsi and other prominent Ibos as a revenge for acts believed to have been perpetrated by Ibos which led to the Biafra-Nigeria civil war (1967-1970). The request for reparation of $\$ 100$ billion included in the document was criticised, while opponents of the request preferred a request or proposal for the prevention of a similar event in the future (Igwe 2005). The reasons for the Biafra-Nigeria civil war included quarrels over shares of national resources allocated on the basis of the population size of the constituent ethnic groups. Akam (2007/8) showed that there was a politically contrived manipulation of headcount in Nigeria to favour the Hausa-Fulani as the most populous ethnic group. To achieve this, the population of Ibos, which was the largest, at 3,930,509, i.e., $36.7 \%$ of the total $(10,718,920)$ in the 1921 census, had been systematically reduced thereafter to only $3,184,585$ in the 1931 census, and to $12,399,462$ $(22.3 \%)$, or the third largest of the total $(55,670,052)$ in the controversial and disputed 1963 census as well as the 1991 one (Akam 2007/ 8: 26-27).

\section{Objectives}

The general objective of this article is to highlight the destructive regional inequality arising from marginalising policies of Nigeria's federal government agencies working in collaboration with one of the six states in the South-South region (Akwa Ibom) against its neighbour (Cross River). The specific objective is to show how ongoing and recent marginalisation in the form of inequitable/unjust allocation of shares of earnings from the export of crude oil extracted from Cross River State's offshore territory could exacerbate inequality in the region's educational fortunes in the near to long-term future of the South-South region of Nigeria.

\section{Organisation of the paper}

The rest of this paper is organised in various sections. In the next, we present the context (socio-demographic, geographical, economic, and political) of the study areas exhibiting increasing inequality between the two states examined, which were originally one political entity named the South-Eastern State, later renamed (old) Cross River State, before 
a new state (Akwa Ibom) was created out of it, thereby leaving in existence the new Cross River State. Then we bring theoretical perspectives of marginalisation into the discourse of inequality in the study areas as a way of contributing to the understanding of inequality afflicting the rest of socio-cultural groups marginalised in Nigeria's South-South region and elsewhere in the country. Considering the diversity of new issues brought into the discourse on the geographies of neoliberalism and neoliberalisation, we seek to place the discourse on marginalisation, using references to selected theoretical literature, as one of its new and widening sub-fields or aspects. We follow on by showing the relationships between human capital and regional development outcomes at global and local (sub) national scales, and the way ethnic crises influence, affect and determine national development in $\mathrm{Ni}$ geria. Afterwards, we describe the methods, data and sources of data used in the study. The next section presents our findings, including recent development circumstances of Cross River and Akwa Ibom States that provide grounds for the consolidation of inequality in human capital development resulting from increasing oil-windfall (financial resources allocated from the federal government pool) to Akwa Ibom State, compared against Cross River State's declining oil revenue and education policy. Then we draw on extant literature to confirm inequality and variability in educational attainments in Nigeria by sub-national regions since the colonial and post-colonial eras, and specifically draw from recent reports/analyses informing that the leading position of the Yoruba (a south-western Nigerian cultural group) is attributable to the free education policy implemented by the region's former governor - the Premier and political leader from the 1950s until the present. Then we comment on how Cross River State's recent dwindling revenue is attributable to marginalisation by agencies and departments of Nigeria's federal government. Finally, we conclude the paper and recommend a policy for improvement.

\section{Growing inter-/intra sub-regional inequality}

The visibility of growing inequality between the two states - Cross River and Akwa Ibom - is enhanced by reflecting on their shared geo-political history and homogeneity. They existed originally as one of Nigeria's 12 states under the name of the South-Eastern State since its creation in May 1967 and continued functioning so until $1^{\text {st }}$ September 1987 when Akwa Ibom State was carved out of it as a separate entity. This political action by Ibrahim B. Babangida, one of Nigeria's many dictators (1985-1993), further diverted attention from the need to accord equal recognition to all of Nigeria's old provinces, most of which were turned into some of Nigeria's 36 states during successive acts of creating states and Local Government Areas. The old Ogoja province is one of those old provinces of the 1950s that were neglected as partners and coalesced to form the old Cross River State. It was this form and name that General Muritala R. Muhammad, another dictator, picked upon during Nigeria's second state-creation exercise in 1975 and merely imposed a nomenclatural change (from South-Eastern State to Cross River State) rather than applying territorial re-organisation by way of state creation that the more politically savvy representatives of ethnic nationalities used in order to get larger shares of the 'national cake' - a common description of the sharing of income derived from petroleum oil sales. Thus, the old Ogoja province remains one of the most seriously marginalised, under-developed and excluded when compared with other former provinces of the 1950s and 1960s. Thus, the renaming of the state in the mid-1970s merely recognised the Cross River, a river originating in the Cameroon mountains, draining into Nigeria through the state's north-central parts in complex meanders before emptying into the southern Atlantic Ocean (Ojo \& Adebayo 2008, Alapiki 2005).

With an area of $6,900 \mathrm{~km}^{2}$, Akwa Ibom State is only $31.7 \%$ of the area of Cross River State $\left(21,787 \mathrm{~km}^{2}\right.$; National Bureau of Statistics, NBS, 2006). Although Nigeria's ethnic groups have not been rigorously ranked in terms of their population sizes, the haphazard claims about the prominence of some of them place the Ibibio, Annang and Efik cultural groups ahead of the multiplicity of cultural groups (Ekori, Bette, Bekwara, Ejagham, among others) constituting Cross River State. The state is described by most documents that attempt to represent it graphically as hav- 
ing an ocean/sea-ward boundary in its southern extreme (Cross River State, n.d.: 2, 4). Moreover, Cross River State possesses one of Nigeria's largest sea-ports (the third largest) on which the pioneering Export Processing Zone and later Free Trade Zone was established by the Babangida dictatorship from the Calabar sea port, which had earlier been commissioned on $9^{\text {th }}$ June 1979. The Calabar sea port's compulsory pilotage area (described as District A) is demarcated by the following coordinates: latitude: $04^{\circ} 01^{\prime} .6 \mathrm{~N}$; longitude: $007^{\circ} 24^{\prime} .4 \mathrm{E}$; latitude: $04^{\circ} 30^{\prime} .3 \mathrm{~N}$ and longitude: $008^{\circ} 24^{\prime}$.E (Cross River State, n.d.: 20-21). The judgement of the World Court in The Hague in the Netherlands in the late 2000s ceded some of Nigeria's territory around a part of Cross River State called Bakassi to the Cameroon Republic, causing the state to lose parts of Bakassi. Bakassi has been part of the Calabar area of the Efik kingdom led from historical to the current administrations by a monarch, Obong (King) of Calabar. Therefore, the area of the state declined from $23,000 \mathrm{~km}^{2}$ in 2005 to 21,787 after the hasty judgement (Cross River State Planning Commission 2005: 30, National Bureau of Statistics 2006: 2).

Like Cross River State, Akwa Ibom State also has an ocean-ward boundary at its southern extreme. Therefore, the two states have been treated as littoral states and by that virtue have been getting shares of the earnings from the export of crude petroleum oil extracted from Nigeria's offshore territory since this principle of revenue sharing came into force (around the 2000s).

\subsection{Population}

The population of Cross River State in 2006 was 2.9 million, an increase from 1991 with its 1.9 million (National Bureau of Statistics 2007, National Population Commission 1991). The population of Akwa Ibom State rose to 3.9 million in 2006 from its 1991 population of 2.41 million (National Bureau of Statistics 2007).

\subsection{Economy}

Official information puts both states as being among the 11 southern Nigerian states which had poverty rates higher than the national average in the mid-2000s (National Bureau of Statistics 2005: 28). In 1996 and 2004 the poverty incidence in the entire country were $65.6 \%$ and $54.4 \%$, respectively, as against $65.5 \%$ and $71.73 \%$ in Akwa Ibom State and $66.9 \%$ and $41.61 \%$ in Cross River State (National Bureau of Statistics 2005: 69). Agricultural and non-agricultural occupations were, respectively, $21.24 \%$ and $78.76 \%$ in Akwa Ibom State and $29.97 \%$ and $70.03 \%$ in Cross River State, as against $21.54 \%$ and $78.46 \%$ for Nigeria (National Bureau of Statistics 2005: 76).

Since the non-agricultural occupations collectively represent a wide range of occupations, the above figures confirm the claim that agriculture is the largest employer of the population of both states. This was also the case when the two states were one Cross River State, with the proportions of the population in agriculture and non-agricultural activities in the South-South zone including Akwa Ibom and Cross River States being 20.90\% and $79.10 \%$, respectively. The relative poverty rates were $25.15 \%$ as "core poor", $37.45 \%$ "moderately poor" and $37.40 \%$ "non-poor" for those in agricultural occupations (National Bureau of Statistics 2005: 45-46).

\subsection{Linking marginalisation theory to inequality between Akwa Ibom and Cross River States}

The concept of marginalisation has been used to refer to the act of exclusion of some people from important processes and aspects of national life in ways that result in the stultification of the victims of the act in terms of socio-economic and political growth and advancement. It is undertaken in several ways, including the keeping of its victims at the periphery of national life and its processes. It could take the form of presenting them as people who constitute threats to national and society's security as an excuse for perpetrating acts of exclusion against them, e.g. keeping them out of appointments into positions admitting them into the élite or top functionaries of the government or administration. It also manifests itself in the form of deliberate misapplication of public institutions in ways that can hamper the progress of the victims, conducting a campaign 
of calumny or misrepresentation of the victimised group, and matching such campaigns with complementary legal provisions. These include constitutional instruments such as laws and legal provisions designed to legitimise marginalisation perpetrated against the victims.

The concept is mild, rather polite, and implies a less rancorous nature of protests against the oppression practised by the ruling class or group. Therefore, the prospective élite who employs the concept proceeds in a way that seeks to sustain the relationship with the status quo rather than breaking it by means of bloodshed. The fact that it is more easily resolved through the use of bold administrative and political measures distinguishes it from other injustices, which because of their deeper roots require constitutional reforms, amendments, and even revolutions to resolve. The potential of marginalisation to destroy its victims is enormous. Although it is usually not written into legal documents and statutes of a country in which it is practised, it is inflicted on

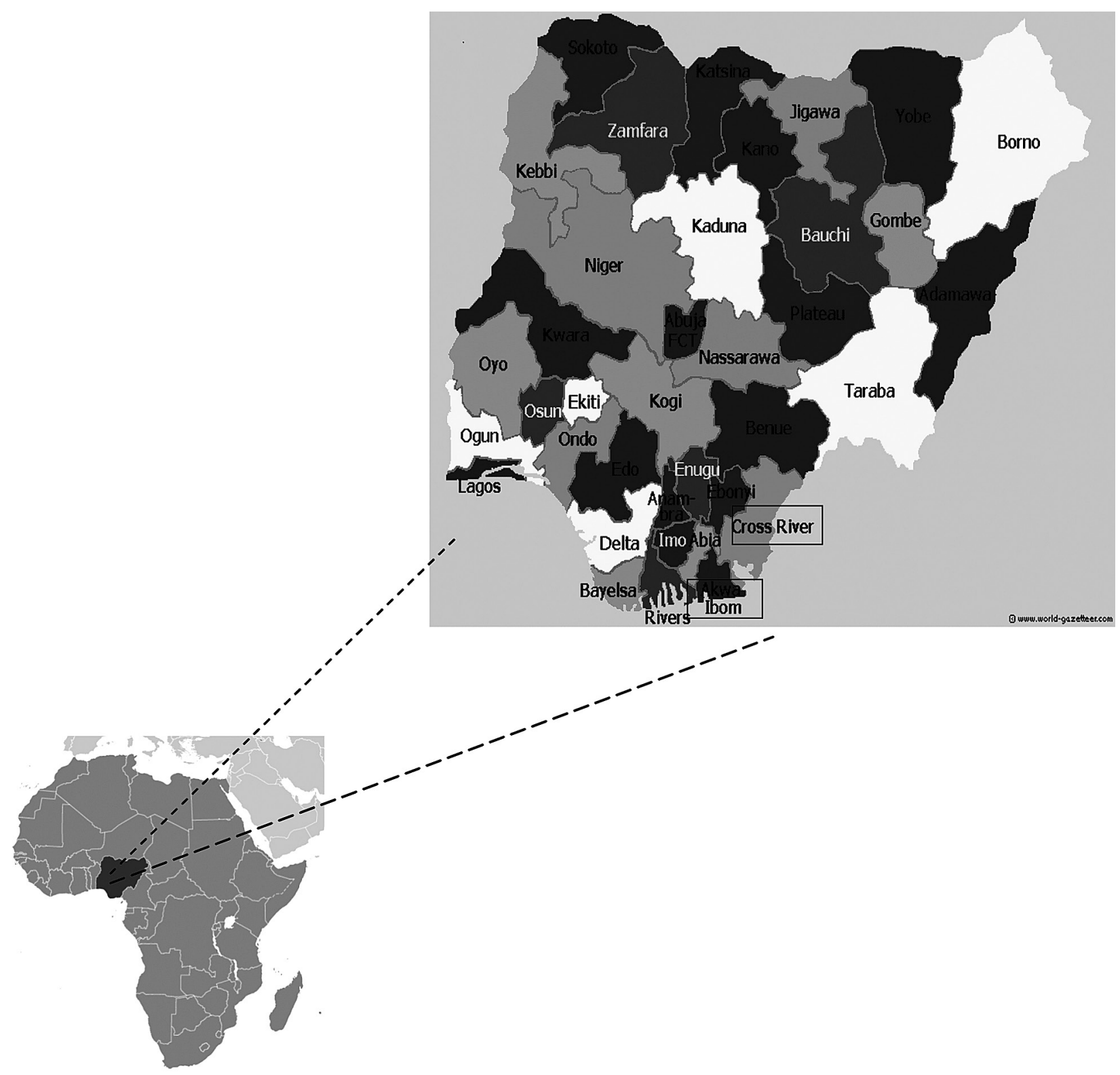

Fig. 1. South-South/Eastern Nigeria, including Akwa Ibom and Cross River States.

Source: Africa with Nigeria inset retrieved 25 January 2013 from http:/ / www.worldofcultures.org/ 1024/ africa/ AfricaMaps/nigeria.gif; Nigeria with States and FCT retrieved 25 January 2013 from http:/ / mapsof.net/ nigeriaciting www.world-geographics.com; Ingwe (2012). 
its victims in various ways. These include mass mobilisation and a systematic creation of a bias against its victims as well as the execution of a long-term campaign against those victims, including the trivialisation of their problems and their protests.

These insidious characteristics of marginalisation have been observed in most parts of the world, including the Niger Delta, a region inhabited by several ethnic nationalities (Ijaw, also known as Izon, Ogoni, Efik-Ibibio, Urhobo, and Itsekiri, among others) in Nigeria's South-South region. This affliction occurs in the neighbouring south-eastern part of the country, especially the settlements of the Ibo socio-cultural group that excludes the Yoruba, while other socio-cultural minorities are spared this maltreatment. Marginalisation might also manifest itself in the form of the downplaying of the existence of some people as non-existing minorities, as in the cases of those of northern Nigeria under the shadow of the Hausa-Fulani, who are presented as dominant. The northern minorities include: Tiv, Igala, Idoma-Gbayi, Ebira, Nupe, Southern Zaria, Angas, and Jukuns, among others. Elsewhere in Africa, marginalisation has been reported in several places, e.g. in Rwanda and Burundi, where the majority Hutu people charge the Tutsi with marginalisation. The creation of a just, democratic leadership and good governance favourably disposed to the institutionalisation of policies of fairness, justice and the rule of the law, as well as the execution of development policies that engender equality among the various regions, classes of citizens and groups, have been suggested as antidotes or solutions to charges of marginalisation (Igwe 2005: 250-251). The democratic systems in Africa are fragile and susceptible to ethnic-based violence. For example, there are debates about the violence arising from the post-27 December 2007 elections in Kenya involving ethnically based killings, demonstrations, and trial of suspected sponsors at the International Criminal Court thereafter. Previously and immediately after the violence, it prompted the modification of the government led by Mwai Kibaki into one of national unity that co-opted Raila Odinga of the Rainbow Coalition, reflecting charges of marginalisation by some ethnic groups (the Kikuyu of Kenya) over a long time since the political re- gimes of the late Jomo Kenyatta since the country's independence (Markussen \& Mbuvi 2011, Murunga 2011).

\section{Human capital policies and regional development outcomes}

The concept of human capital development has gained ascendancy in the policy sphere of most development-planning agencies of several countries due to the discovery that it contributes much more to national development outcomes than physical infrastructure. Recent estimates put the contribution to national wealth of human capital-related variables (describing the stock of education, training, skills and health acquired by people) at about $75 \%$, as against a mere $15 \%$ contributed by the stock of physical capital, including minerals and natural resources. Owing to this knowledge, some scholars have undertaken analyses of the ways nations and regions invest in the development of human capital as compared with physical capital, in Nigeria and elsewhere (The National Scholar 2002: 1, citing Andy Rosenfield). They have documented increasing attention that various national governments have concentrated upon education, or more precisely, their investment in this sector. For example, Frank Webster regards education as a legitimate foundation for building a 'weightless economy' (i.e. the new information economy). He justifies this assertion by the fact that education is a source of new technologies, processes and innovations capable of causing an increase in wealth by boosting productivity and generating business. It is a source of 'knowledge workers', i.e. a particular kind of human capital in the information and communication technologies (ICT) sector, which has been credited with engendering spectacular growth in productivity in the USA and other advanced countries for over a decade since information technology was invented and became widely applied. In the contemporary world characterised by rapid obsolescence of specific skills, some central capabilities have been identified, including such human-capital traits as analytical skills, communicative effectiveness, strategic thinking, team work and leadership, which add to an individual's ability to assume responsibility for his/ 
her own career path (Reich 1991, cited in Webster 2001: 132-133). The distinctive recognition of the value of education by a national leader is credited to the former British Prime Minister Tony Blair, who during his government was asked to comment on his position on the high point of national development. His famous response was the litany: "education, education, education" (Webster 2001: 133). The way European cities have successfully implemented spectacular ICT programmes as a means of re-inventing individual local urban economies to increase their competitiveness and productivity brilliantly illustrates the potency of sub-national regional development in the era of post-Fordism.

\subsection{Injustice, inequality and ethnic crisis in Nigeria's development: past and present}

The authors of the articles contributing to Reconstruction and development in Nigeria (Ayida \& Onitiri 1971) after the 1967-1970 civil war by and large downplayed the strong ethnic rivalries that provoked the 31-month military campaign by Biafra (the national platform of the Ibo socio-cultural group) to secede from the Nigerian federation, which they perceived as unjust. However, Onitiri's introduction acknowledges that the war resulted from over "three years of recurring political crises". Successive statements of Nigeria's development objectives in national development plans which followed the war pretended to recognise the serious ethnic rivalry that caused the war. For example, four development objectives proposed by Ayida (1971: 17-18) deserve quoting in extenso here due to their relevance to this article because they were directed at Nigeria's future (i.e. the 1970s, the period that followed the war of ethnic rivalry and quarrels or crises):

"... first, the rehabilitation of the war-damaged areas of the country and the reconstruction of the economy as a whole in order to correct the generally accepted weaknesses of past (economic development) and present (war-time financial) policies;

Fifth, the maintenance, as far as possible, of a balanced development of the national economy by concentrating on growth points and productive capacities rather than, but not to the exclu- sion of, the provision of subsidized social services in the economically backward areas of the country;

Sixth, the production of high-level and intermediate Nigerian manpower to satisfy the requirements of the public and private sectors, including the replacement of the build of the expatriate personnel in industry and commerce by 1980; this could imply, for example, the production by 1980 of a cumulative total of about 55,000 Nigerian university graduates, mainly from institutions of higher learning in the country; and

Seventh, the provision and maintenance of a satisfactory level of social services which the economy and the people can bear at any given time".

In proposing prospects for effective development planning machinery for Nigeria many decades ago, one of Nigeria's development planners, Eniola O. Adeniyi (1980) drew attention to some pertinent factual issues. He states that: "In a federation as we have in Nigeria, processes which bring about dynamic equilibrium between centrifugal and centripetal forces are always at work. Adjustments are continuously being made in the relationship between the federal and state governments which are in the direction of further economic integration in the country. Nigeria of the 1980s, unlike in the First Republic (1960-1967), cannot be said to desire union but purposeful unity to her economic and social relationships" (1980: 294-295).

\section{Methods and data}

We used the methods of comparison, description, and case study to show various regional development scenarios in Akwa Ibom and Cross River States. As documented in the literature, the method of comparison (Scott \& Marshall 2005) enabled us to highlight differences in education development scenarios of the two states using available indicators. Several methodologists have demonstrated the appropriateness of description as a veritable method for achieving the objectives that have previously received scant attention by academic researchers (e.g. Ogunniyi 1992, Isangedighi et al. 2004). Our objective (of highlighting inter-/intra-regional inequity involving a com- 
parison of regional development scenarios in Akwa Ibom and Cross River States) has, by and large, been ignored by researchers. Instead of undertaking sophisticated data analysis, we rapidly compared and aggregated education-related indicators of both states, using data provided by the Federal Ministry of Education and the National Bureau of Statistics to highlight variations in the recent education scenarios (performance), thereby pointing towards future scenarios for the education sectors of the studied states.

We extracted and used data/information on relevant variables and attributes from secondary sources. The National Bureau of Statistics (NBS), Nigeria's official agency responsible for providing statistics for development planning and management, provides reliable data on education and many other sectors of development on a national basis. The data are generated by the collaboration between the NBS, the World Bank and other stakeholders to create statistics on poverty and poverty-monitoring initiatives. The latter, which include data on poverty and well-being, among other related conditions, were derived from two data generation exercises undertaken by the NBS: the 2006 Core Welfare Indicator Questionnaire (CWIQ) and the 2007 Multiple Indicator Cluster Survey (MICS). These pertain to the education sectors of the 36 states and the capital (Abuja) from which data covering the two study areas (Cross River and Akwa Ibom States) and their wider geopolitical (South-South) region were extracted for analysis. The reliability of the NBS data arises from its partnership with the Federal Ministry of Education, which has been using the International Standard Industrial Classification on Education (ISICE) since 1978 to generate education data. Additionally, it employs trained teachers to take censuses whereby data on 53 attributes of primary and secondary levels of education, including those of interest to this study, are collected on the annual Education Statistics Day, which falls on the last Wednesday of March every year (National Bureau of Statistics 2007: 945-999). Although we stress the future human capital development scenarios of the two states studied, we included other related regional development indicators of the states. Our analysis involved the use of a combination of simple quantitative and qualitative techniques of data processing.

\section{Findings}

\subsection{Educational characteristics of Cross River and Akwa Ibom States}

In what follows, we present educational characteristics indicating inequality in this respect between the two states. Table 1 reveals that here Cross River State - the older region - is either lagging behind or out-competed by its younger neighbour, Akwa Ibom State. That is, the latter performed better in most aspects of the education sector.

Cross River State's educational backwardness predates the above more recent statistics on education. It is believed that while the people of Akwa Ibom State were still part of the old Cross River State, the unwritten policy of marginalisation was practised systematically to ensure that Akwa Ibom people got greater educational opportunities than Cross River people. The consequence is that while the Cross River State government and other institutions of the federal government of $\mathrm{Ni}$ geria regard it as 'educationally disadvantaged', Akwa Ibom State is not described in such terms. Rather, it is reputed to possess a great number of good-quality human capital, including university professors, other highly educated people in the professions, and so forth. Federal government institutions, including the Joint Admissions and Matriculations Board, the agency mandated to process the admission of candidates into tertiary educational institutions in Nigeria, have officially recognised the degree of 'educational disadvantage' of Cross River State. This suggests that Nigeria's Federal Ministry of Education, among other institutions, recognises this tragic circumstance of Cross River State.

\subsection{Future scenarios of educational and human capital attainments in Cross River and Akwa Ibom States}

We use the duration (in years) of schooling, or formal education, from the basic primary school, through secondary schools to the tertiary educational institutions, as a schedule for our projection. Recently, the Federal Ministry of Education has approved the duration of education in Nigeria to be six years of basic primary school; three 
Table 1. Educational characteristics of Cross River State and Akwa Ibom State.

\begin{tabular}{|c|c|c|c|}
\hline No. & Characteristic & Cross River State & Akwa Ibom State \\
\hline 1 & $\begin{array}{l}\text { Total net attendance rate of children of primary-school entry } \\
\text { age attending primary or secondary school, and number of } \\
\text { children of primary-school entry-age (in brackets) (2007) }\end{array}$ & $95.0(518)$ & $92.1(613)$ \\
\hline 2 & $\begin{array}{l}\text { Rate of primary school completion and transition to second- } \\
\text { ary education, and number of children who were in the last } \\
\text { grade of primary school the previous year (in brackets) (2007) }\end{array}$ & $100.00(90)$ & $87.1(102)$ \\
\hline 3 & $\begin{array}{l}\text { Percentage of children of primary-school entry age currently } \\
\text { attending grade } 1 \text { (2007) }\end{array}$ & 55.8 & 61.1 (higher/better) \\
\hline 4 & Adult literacy rate (2006) & 75.5 (higher/better) & 67.0 \\
\hline 5 & Primary-school net enrolment (2006) & 77.0 & 77.4 (higher/better) \\
\hline 6 & $\begin{array}{l}\text { Total net attendance rate of children of secondary-school age } \\
\text { attending primary school (2007) }\end{array}$ & 15.7 (higher) & 9.0 (better) \\
\hline 7 & $\begin{array}{l}\text { Children of primary-school age attending primary or second- } \\
\text { ary school (2007) }\end{array}$ & 95.0 (higher/better) & 92.1 \\
\hline 8 & $\begin{array}{l}\text { Total net attendance rate of children of secondary-school age } \\
\text { attending secondary/higher school (2007) }\end{array}$ & 70.7 (higher/better) & 69.5 \\
\hline 9 & Level of literacy among women aged 15-24 years (2006) & 78.7 (higher/better) & 77.8 \\
\hline 10 & Youth literacy (age 15-24, 2006) & 90.7 (higher/better) & 83.7 \\
\hline 11 & Secondary-school net enrolment (2006) & 62.4 (higher/better) & 45.0 \\
\hline
\end{tabular}

Source: the authors' compilation from several issues of Nigeria's National Bureau of Statistics (NBS), over several years (2005, 2006, 2007a, b).

years of junior secondary schooling; three years of senior secondary schooling, and four years of ordinary (i.e. non-professional) university education. This programme has become popularly known as the 6-3-3-4 system of education. While it takes longer than four years of tertiary education for students to graduate in the professional areas, we prefer to keep our projection simple by using the 6-3-3-4 system, which makes a total of 16 years to produce a graduate of tertiary educational institutions in Nigeria. Therefore, we fix the point at which a radical inequality in educational attainment will appear between Akwa Ibom and Cross River States at 16 years into the future, using the year of the promulgation of the free education policy in Akwa Ibom State, i.e. 2008, as the base year from which the projection starts.

Thus, by the year 2024, a substantial proportion of children who were of school-going age in Akwa Ibom State from 2008 onwards would have achieved higher levels of educational attainment than their counterparts in Cross River State. By the year 2015, Akwa Ibom State will have achieved the Millennium Development Goals (MDGs) pertaining to basic (primary) education, while Cross River State may not have achieved the MDGs, or if it does, it will have done so to a lower degree than the outcomes facilitated by the free education policy of Akwa Ibom State.
The higher educational attainment in Akwa Ibom State is likely to be similar for all three levels of education because of the growing number of various kinds of tertiary and secondary educational institutions in the state. For example, the Akwa Ibom State University of Science and Technology and other tertiary institutions, such as those training in petroleum oil engineering and technology, as well as several other polytechnical and monotechnical schools, appeared in the past few years of the Fourth Republic (1999-2011).

Additionally, the Akwa Ibom government has put in place several financial assistance programmes, such as scholarships, bursaries, grants and so forth, to support students of the state's origin in tertiary (undergraduate and postgraduate) educational systems. This will ensure that the inequality in human capital levels will be polarised in favour of Akwa Ibom State.

\subsection{Persisting inequality in regional educational attainment in Nigeria: Evidence from comparing the South- Western region's free education policy against the rest of the country}

Recently, Ingwe et al. (2011) confirmed the previous finding that the Yoruba inhabiting six 
states in south-western Nigeria (Ekiti, Lagos, Ogun, Ondo, Osun, and Oyo) possessed the highest number of tertiary educational institutions and perhaps the highest level of educational attainment in Nigeria compared with other numerous ethno-cultural groups constituting the country's remaining 30 states. This feat is attributed to the free education policy implemented by Obafemi Awolowo, former Premier of the region in the 1950s and political leader up to the 1980s. While the Yoruba are generally rated to be the best educated, it is less clear regarding the wide acknowledgement of the Ekiti as being on top of the education sector within the Yoruba land, with the highest number of their academic professors compared with other Yoruba states and, of course, the rest of Nigeria. Therefore, it is indubitable that free education policy translates into higher educational attainment at various levels, from basic (primary) to tertiary (Ingwe et al. 2011, Fafunwa 1967, 2004).

\section{Discriminatory oil revenue allocation and deepening inequality in human capital development in Akwa Ibom and Cross River States}

The declaration of a free education policy by the government of Akwa Ibom State in 2008 provides a good basis for simulating and projecting the inequality that will emerge between Akwa Ibom State and its neighbour, Cross River State. The former's policy of free education is suitable for making the simulation for several reasons, a few of which will be stated here. The policy mandates all parents to ensure that their children and wards take advantage of the opportunity that the Akwa Ibom State government has provided for the children and youth of the state to acquire free and compulsory education. This policy is facilitated by the disproportionately higher allocation to Akwa Ibom State of about N14 billion monthly of the 13\% share, according to the oil derivation principle, due to the belief that its offshore territory contains oil resources commensurate to that share, while Cross River State received only $\$ 1.5$ billion for its oil resources - a difference of 12.5 billion. The more recent striking of Cross River State from the list of offshore oil-producing areas or littoral states in March 2009, despite its vast onshore petroleum oil resources included by the federal government in the national oil reserve classification, is bound to worsen the budgetary capacity of Cross River State and at least create difficulties in adopting its own free education policy of the kind implemented in Akwa Ibom State. However, the propriety or otherwise of these revenue-sharing considerations is secondary in this paper, attention being concentrated upon the inequality in future educational or human capital development outcomes in the two states.

\subsection{Cross River State's dwindling revenue and Nigeria's federal government marginalisation}

Information about the striking of Cross River State from the list of Nigeria's littoral areas, i.e. those with ocean-ward boundaries qualifying them for receipt of the $13 \%$ share of the revenue accruing from crude oil export, highlights the prominence of two major agencies of the federal government of Nigeria in the decision of March 2009. Those are the National Boundary Commission (NBC) and the Revenue Mobilisation and Fiscal Commission (RMAFC). They informed the public, including stakeholders, the Accountant-General of the Federal Republic of Nigeria, as well as the governments and peoples of Akwa Ibom and Cross River States, that in January 2009 Cross River ceased to be a littoral state and so forfeited its monthly $13 \%$ share based on oil resources exploitation from Nigeria's offshore territory. This letter contradicted the NBC's letter (Reference No: NBC/SEC32/1/485) of 4 January 2005 reporting that, following its delineation of the maritime boundary between the two states, "Cross River State will gain 76 oil wells". The government of Cross River State sued the NBC, RMAFC and its parties, seeking to restrain them from "enforcing or acting upon any other maritime or estuarine boundary alleged to exist between the two states, except that determined by the NBC in 2005 and accepted by the parties, which had been in use for revenue sharing purposes for several years, pending the determina- 
tion of the substantive suit" (Adekeye et al. 2009: 38).

An earlier action of the federal government that smacks of the marginalisation of Cross River State was the rather easy concession of part of the state's territory (the oil-rich Bakassi Peninsula) to the Cameroon Republic in 2005 ignoring the Efik people, a socio-cultural group whose traditional kingdom originally owns and administers the Bakassi region, who consider the presentation made by the federal government at The Hague considering the Efik ownership of and entitlement to the Bakassi area to be weak and not strong enough. The Efik and Cross River people argued that Nigeria's federal government was wrong in delegating persons ignorant of the Bakassi region's history, geography, sociology, anthropology and politics, or knowledge required for providing stronger evidence to The Hague-based World Court of Justice in The Netherlands, instead of the Efik custodians and owners of the Bakassi Peninsula. Moreover, they argued that the British government which claimed to have conceded Bakassi to the Germans during the heydays of colonialism did so wrongly, because Bakassi was not part of the British territory during colonialism as they claimed. The World Court judgement, according to the people of Cross River State and the Efik, was delivered without hearing appeals on these and related points in issues well known in Cross River State. Additionally, while the delegation of Nigeria's federal government to the World Court had more delegates who were interested in winning some territories currently in north-eastern Nigeria from Cameroon, the Efik historians, geographers, sociologists, politicians, anthropologists etc. could also have provided ample evidence of the ownership of Bakassi by Cross River State, but were marginalised and the strength of the representation weakened in terms of the number of representatives, resources and opportunities for preparing evidence. Therefore, the attempt to seize 76 oil wells from Cross River State for the benefit of Akwa Ibom State stimulated moves by Cross River State to appeal against the Bakassi ceding to Cameroon (The Village Square, a discussion programme broadcast by the Cross River Broadcasting Corporation Television between May and June 2009).
The panel contributors to the publicly televised focus group serial discussion perceived the decisions of the Nigerian Boundary Commission as inappropriate for the following reasons. First, the NBC's ceding of the 76 oil wells hitherto belonging to Cross River State and being an important criterion in attracting oil revenue, to Akwa Ibom State disproportionately increased the latter's number of oil wells and revenue. Second, in taking this action, the NBC preferred to ignore that Cross River State still possessed an oceanward boundary in its southern extreme, but claimed that it was not one of Nigeria's littoral states. Third, the NBC failed to await Nigeria's Supreme Court restraint placed on the NBC's move to re-delineate the maritime and estuarine boundaries between the two states. Fourth, the NBC also failed to await the ruling of the International Court of Justice (in The Hague) on the matter of ceding the Bakassi Peninsula (part of Cross River State) to Cameroon (The Village Square 2009).

\subsection{Cross River State government's response to federal marginalisation}

A major strategy to diversify the economy of Cross River State from sole dependence on the federal government's oil-derived revenue, statutorily shared among all federal states of Nigeria, has been through tourism sector development. When this strategy was initiated in the 2000s, it did not officially anticipate the recent twists involving the removal of Cross River State from the list of the few oil-producing states in the Niger Delta, but the emphasis on tourism development increased after the implementation of the policy of the state's marginalisation. Some evidence can be found in the several speeches made by the State Governor, Senator Liyel Imoke, who has consistently urged the State's Cabinet (Executive Council), citizens, friends and supporters to identify and harness other alternative sources of revenue to fund development programmes in the face of the stoppage of federal allocations from oil-derived funds. In this connection, tourist products developed by Cross River State attract the attention and patronage of the African regional and global community. This is especially 
true of two out of the State's many tourist projects. One is the phenomenally successful annual 31-day long Calabar Festival, fondly described as Africa's Largest Street Party, hosted by the Cross River State Tourism Commission in the capital and a free-trade zone city, Calabar. The other is the creation in the Adiabo community in the Odukpani local government area within the outskirts of Calabar city of the TINAPA Leisure and Business Resort, complete with shopping and recreational complexes, including film production studios, emporia and a hotel, that make it comparable to Dubai's trade complexes (Treasure Magazine International 2013, Andrew \& Ekpenyong 2012). However, the size and comparability of the revenue earned from tourism with the State's previous earnings from federal oil-derived coffers is still poorly known.

\section{Conclusion and recommendations}

The above discussion has highlighted issues bordering on marginalisation of Cross River State by the institutions of the federal government of Nigeria, mainly the National Boundary Commission, the Revenue Mobilisation and Fiscal Commission, the Accountant-General of Nigeria's federation, the Ministry of Justice, and others. It has been shown that, strengthened by the benefits of the ceding of the Bakassi Peninsula and more recently 76 oil wells in offshore Nigeria, Akwa Ibom State government has undertaken an ambitious free education policy which ensures that basic primary education is free and compulsory for the children and youths of the state. Since Cross River State has been a victim of what is turning out to be systematic marginalisation, its government cannot bear the cost of undertaking a free education policy of the kind adopted by its neighbour. The attempt to seize Cross River State's 76 oil wells represents an effort to consolidate the existing marginalisation, which includes a greater degree of educational disadvantage in Cross River State than in Akwa Ibom State. We have highlighted the consequences of the ongoing marginalisation in terms of the future inequality in human capital in 2014 when the first batch of pupils have graduated from primary school under the free education policy of
Akwa Ibom State. This will ensure that the state achieves its MDG regarding universal basic education by 2015, and by extension, by 2024, when children who pioneered the free education policy would have graduated from 4-year tertiary educational institutions. When these dates come, Cross River State people and youths will conspicuously lag behind their counterparts in Akwa Ibom State.

Considering the serious consequences of the ongoing and past marginalisation of Cross River State, we recommend that:

1. The Cross River State people and civil society should embark on serious monitoring of all acts that smack of marginalisation by any entity whatsoever as a way of creating programmes designed to counteract it, to make it visible to the federal government and relevant entities capable of redressing the injustice.

2. The federal government of Nigeria should be compelled by Cross River State people and civil society to refrain from further acts of marginalisation.

3. The government of Cross River State should undertake creative educational advancement programmes as a way of addressing the wide inequality in human capital attainment and, by extension, the lower competitiveness of Cross River citizens by 2014 and 2024, and henceforth. We recommend that creativity can lead to the management (after careful planning) of cost-effective educational and human capital development programmes for Cross River State people.

\section{References}

Adekeye F., UbANi M. \& Adewuyi O., 2009. Cross River: Imoke sues RMAFC, National Boundary Commission. TELL (Lagos), 4 May: 38.

ADENIYI E.O., 1980. National development planning and plan administration in Nigeria. In: Ndekwu E.C. (ed.), Proceedings of NISER staff seminar. Nigerian Institute of Social and Economic Research (NISER), Ibadan: 279-302.

Aкам F.U., 2007/08. The politics of headcounts and statistical injustice in Nigeria - Echoes of (the) 2006 Census. Speak, 1(7): 26-27.

AlAPIKI H.E., 2005. State creation in Nigeria: Failed approaches to national integration and local autonomy. African Studies Review, 48(3): 49-65. Retrieved 25 January 2013 from http://www.jstor.org/stable/20065139. 
Andrew E.H. \& EkPenYong I., 2012. Promoting culture and tourism in Nigeria through Calabar Festival and Carnival Calabar. Mediterranean Journal of Social Sciences 3(3): 287-294. DOI: 10.5901/mjss.2012.v3n3p287. Retrieved 6 February 2013 from http:/ / www.mcser.org.

AyIDA A.A., 1971. Development objectives. In: Ayida A.A. \& Onitiri H.M.A. (eds), Reconstruction and development in Nigeria. Proceedings of a National Conference. Oxford University Press for NISER, Ibadan: 1-30.

BAYER K., 2009. 'Neoliberalism' and development policy Dogma or progress? In: Brand U. \& Sekler N. (eds), Postneoliberalism - A beginning debate. Development Dialogue, 51: 89-102.

Cross River State Government, 2009. Report of the Vision 2020 Stakeholder Development Committee for Cross River State, Nigeria. Cross River State Government, Calabar.

Fafunwa A.B., 1967. A History of Nigeria higher education: New perspectives in African education. MacMillan, London \& Lagos.

FAfunWA A.B., 2004. History of education in Nigeria. NPS Educational Publishers, Ibadan.

IGWE O., 2005. Marginalisation. Politics and Globe Dictionary. Eagle Publishers, Aba: 250-251.

INGWE R., 2012. Physical health facilities in Nigeria's sub-national regions: geodemographic and spatial analyses of health institutions in Nigeria's 36 states and federal capital territory. In: Szymańska D. \& Biegańska J. (eds), Bulletin of Geography, 18: 39-54. DOI: 10.2478/v10089-0120018-0. Retrieved 25 January 2013 from http://www. bulletinofgeography.umk.pl; http://www.versita.com/ bgss.

INGWE R., 2013a. Federal government intervention in Hausa-Fulani Almajiri education and Islamic sectarian (Boko Haram)'s terrorism in northern Nigeria: Neoliberalistic hegemonisation of Nigeria's multi-cultural nationalities. Unpublished paper on file at the Centre for Research and Action on Developing Locales, Regions and the Environment (CRADLE).

INGWE R., 2013b. Elitist legislators' equivocation on "transparency, credibility and accountability" of Nigeria's Central Bank, neoliberal-capitalist contradiction and sustainable development. Unpublished paper on file at the Centre for Research and Action on Developing Locales, Regions and the Environment (CRADLE).

INGWE R., 2013c. Governance deficits and nationalisation of sub-national rebellions in Nigeria: The January 2012 rebellion against oil subsidy removal and emerging nationalisation of revolutionary forces. Unpublished paper on file at the Centre for Research and Action on Developing Locales, Regions and the Environment (CRADLE).

InGWE R., IKEJI C.C.C. \& OJONG F.E. 2010. Neoliberal globalisation, financial and economic crises and sustainable development in Africa. ICFAI University Journal of Governance and Public Policy, 5(4): 31-62.

INGWE R., IKEJI C.C.C. \& UGWU U., 2011. Sub-national regional development and degree-awarding tertiary educational institutions in Nigeria: Descriptive, geo-demographic and spatial analysis. Journal of Urban and Regional Analysis, 1: 77-103.

INGWE R., INYANG B.J., ERING S.O. \& AdAliKwu R.A., 2009. Sustainable energy implementation in urban Nigeria. Management Research and Practice, 1(1).

IngWE R., ОкоRо \& IJIM-Agвor, 2012. Neoliberal policies and regimes in post-independent Nigeria at the dawn of postneoliberalism (1960-2007): A research agenda. Universal Journal of Management and Social Sciences, forthcoming.
Isangedighi A.J., Joshua M.T., Asim A.E. \& EKUri E.E., 2004. Fundamentals of research and statistics in education and social sciences. University of Calabar Press, Calabar.

Markussen T. \& Mbuvi K., 2011. When does ethnic diversity lead to violence? Evidence from the 2007 elections in Kenya. Discussion Papers, Department of Economics, University of Copenhagen, 11-19. Retrieved 25 January 2013 from http://www.econ.ku.dk/english/research/ publications/wp/dp_2011/1119.pdf/.

Murunga G.R., 2011. Spontaneous or premeditated? Post-election violence in Kenya. Nordiska Afrikainstitutet, Uppsala, Discussion Paper, 57.

National Bureau of Statistics, 2005. Poverty profile for Nigeria. NBS, Federal Republic of Nigeria, Abuja.

National Bureau of Statistics, 2006. Annual abstract of statistics. NBS, Federal Republic of Nigeria, Abuja.

National Bureau of Statistics, 2007a. Gender and poverty monitoring. NBS, Federal Republic of Nigeria, Abuja.

National Bureau of Statistics, 2007b. The Nigerian statistical fact sheets on economic and social development. NBS, Federal Republic of Nigeria, Abuja: 87.

National Bureau of Statistics, 2007c. Compendium of statistical terms: Concepts, definitions and methodologies for data production and management in Nigeria. Chapter 20: Education. NBS, Federal Republic of Nigeria, Abuja: 945-999.

National Scholar (The), 2002. Insight (Editorial). Publication of the Academic Staff Union of Universities, September 1.

Nigeria, Federal Republic of, 2007. Official Gazette, 94(24): 180-183.

OgunNiYI M.B., 1992. Understanding research in the social sciences. University Press PLC, Ibadan.

Ojo E.O. \& Adebayo P.F., 2008. The politics of states', local governments' creation and Nigeria's search for geo-political balancing. African Research Review, 2(3): 334-367. Retrieved 25 January 2013 from http://afrrevjo.net/ journals/ multidiscipline/Vol_2_num_3_art_22_Ojo\%20 E\% 20\&\%20Adebayo.pdf.

Osaghae E., Ikelegbe A., Olarinmoye O. \& Okhonmina S., 2007. Youth militias, self determination and resource control struggles in the Niger-Delta region of Nigeria. Retrieved 4 February, 2013 from http://www.ascleiden.nl/Pdf/ cdpnigeriaRevisedOsaghae\%5B1\%5D2.pdf.

PEREIRA A.A., 2007. Explaining the enduring comprehensive developmental state in Singapore: A class relations perspective. University of Singapore.

ReIcH R., 1991. The work of nations: Preparing ourselves for $21^{\text {st }}$ century capitalism. Vintage, New York.

Scott J. \& Marshall G., 2005. Oxford Dictionary of Sociology. Oxford University Press, Oxford.

SPEnce M. (ed.), 2008. The growth report: Strategies for sustainable growth and inclusive development. World Bank, Washington, DC.

SPRINGER S., 2010. Neoliberalism and geography: Expansions, variegations, formations. Geography Compass, 4/8: 10251038.

SPRINGER S., 2011. Articulated neoliberalism: the specificity of patronage, kleptocracy and violence in Cambodia's neoliberalisation. Environment \& Planning A, 43: 2554-2570.

SpRINGER S., 2012a. Neoliberalism as discourse: Between Foucauldian political economy and Marxian poststructuralism. Critical Discourse Studies, 9(2): 133-147.

SPRINGer S., 2012b. Neoliberalising violence: Of the exceptional and the exemplary in coalescing moments. AREA (Royal Geographical Society), 44(2): 136-143. DOI:101111/j1475-4762.2012.01084.x 
State Planning Commission, 2005. Cross River State economic empowerment and development strategy CR-SEEDS 20052007. State Planning Commission, Calabar.

UKWAYI J.K., INGWE R. \& OJONG F.E., 2012. Geodemography of health care services in the budding tourism destination of rapidly urbanising Cross River State, South-East Nigeria. Romanian Review of Regional Studies, VIII(2): 67-86.

UNDP, UNEP, World Bank \& WRI, 2005. World Resources 2005: The wealth of the poor (Managing ecosystems to fight poverty). World Resources Institute (WRI), Washington, DC: 254.
Village Square (The), 2009. Panel discussion on RMFAC's ceding of Cross River State's 76 oil wells to Akwa Ibom State in 2009 and previous ceding of Bakassi Peninsula to Cameroon and related issues with Drs. Ambrose Akpanika, Okpo Ojah, and Nelson Coco-Bassey. Cross River Broadcasting Corporation (CRBC) TV, May-June.

WeBSTER F., 2001. Re-inventing place: Birmingham as an information city? In: Kasvio A., Laitalainen V., Salonen H. \& Mero P. (eds), People, cities and the new information economy (Materials from an international conference in Helsinki, 14-15 December 2000). Palmenia Kustannus, Helsinki: 128-152. 